\title{
Needs Assessment of Saudi University EFL Teaching Assistants
}

\author{
Nasser M. Freahat (Corresponding author) \\ E-mail: nmfreahat@imamu.edu.sa
}

\begin{abstract}
Rana A. Alshowaier
Faculty of Languages and Translation, Imam Mohammad Ibn Saud Islamic University

E-mail: ranaalshowaier@hotmail.com
\end{abstract}

Received: March 12, 2019

Accepted: April 20, 2019 Published: April 23, 2019

doi:10.5296/elr.v5i1.14485

URL: https://doi.org/10.5296/elr.v5i1.14485

\begin{abstract}
This study aims at investigating Saudi university English as a foreign language (EFL) teaching assistants' linguistic, pedagogic and technological needs. The sample of the study involves (52) female and (32) male teaching assistants all working in the department of English language and literature at Imam Mohammad ibn Saud Islamic University (IMSIU) in the second semester of the academic year 2016-2017. The study employed a questionnaire to answer the research questions. The results demonstrated that Saudi teaching assistants are in dire need to improve their competences. Based on their responses, technological competence ranks as the most needed skill which indicates that they were willing to implement Computer Assisted Language Learning (CALL) in their classroom. The study also showed that linguistic competence was the second most needed competence while the pedagogic competence is the third most needed skill to be mastered. Saudi teaching assistants need systematic assessment of the linguistic, pedagogic and technological competences as the core criteria for success in the teaching process.
\end{abstract}

Keywords: Needs analysis, Professional development, Teaching assistants' needs, Linguistic needs, Pedagogic needs, Technological needs

\section{Introduction}

English in Saudi Arabia has become the major foreign language to be taught in schools, colleges and universities. Therefore, the Ministry of Education in Saudi Arabia has implemented multiple professional development (PD) and in-service training programs in order to enhance teaching practices for teachers (AL-Zahrani, 2017). A number of studies 


\section{Ml Macrothink}

have explored the current state of FL teacher development to improve the professional state of future teaching assistants (TAs). The 2007 Modern Language Association report suggested that graduate students receive training in new technologies due to the fact that computer-assisted language (CALL) has advanced tremendously. So, it is important for TAs and teachers in general to pay attention to publications that focus on technology (Angus, 2014). Thomas (2013) surveyed TAs who showed that power point, website for teaching grammar, and discussion board were of great importance in addition to their being beneficial as well as popular. Several TAs reported that they did not feel confident about themselves and their abilities to use CALL in their courses. To overcome this, Thomas suggested incorporating more technologies especially Web 2.0 technologies into the methods course. Scott (1998) reported that using the Internet helped facilitate TAs reflection. Arnold and Ducate (2006) used data from surveys to determine that online discussions where helpful in enhancing a deeper understanding of the course material in addition to creating interactions. So, TAs need to be fully prepared to use new technologies and make appropriate education decisions about how and if they can apply these technologies in their classes.

\subsection{Statement of the Problem}

Based on related studies (Al-Hazmi, 2003; AL-Seghayer, 2005; 2014; Khan, 2011; Rahman \& AL-Haisoni, 2013), some EFL Saudi teaching assistants (TAs) are still lagging behind in approaching the required educational strategies and practices pertaining to the teaching process in Saudi Arabia. To some extent, some are professionally and linguistically incompetent in addition to not having a strong hold of methods of teaching language. A lot do not have the theoretical background knowledge of the basic factors of second language learning such as motivation, aptitude, age and attitude. Some English teachers also may not have the experience needed in material design, evaluation and adaptation. Therefore, this research assesses the professional needs of Saudi EFL teaching assistants.

\subsection{Purpose of the Study}

The current study aims at assessing the Saudi EFL teaching assistants' professional needs at Al-Imam Mohammad Ibn Saud Islamic University(IMSIU)in order to help them increase their motivation in the educational process and improve their professional potentialities. More specifically, the study aimed at investigating Saudi university EFL teaching assistants' linguistic, pedagogic and technological needs.

\subsection{Research Questions}

The study sought to answer the following research questions:

1) What are the Saudi university EFL teaching assistants' linguistic needs?

2) What are the Saudi university EFL teaching assistants' pedagogic needs?

3) What are the Saudi university EFL teaching assistants' technological needs?

\subsection{Significance of the Study}

This study assists EFL teaching assistants' needs at IMSIU attempting to enhance the quality of teaching EFL students. The findings may also have the potential to inspire the Ministry of Higher Education and educators who are responsible for developing the process of EFL teaching with a vision of the professional development needs of EFL teachers in Saudi universities in an attempt to develop their quality of teaching and learning outcomes. 


\section{Literature Review}

Many people have attempted to define the term needs analysis which helps in understanding its constituents. A needs assessment is an approach that studies the ability, knowledge and attitude of a specific group who are interested in a particular subject. A needs assessment helps in making decisions about required needs through which educators can extend the effect of educational programming (McCawley, 2009). Many asserted that needs assessment is a must in the process of teaching and is an important part of teachers' daily practice particularly in the field of teaching English EFL worldwide (Hopkins, Stanley, \& Hopkins 1990). They assert that "some form of assessment is inevitable; it is inherent in the teaching-learning- process" (p. 194). Assessment in this way is integral for instructors who teach English (EFL teachers) to assess their competences and guarantee professional development as part of their professional success. Thus, assessment is considered to be an integral part of teachers' daily practice in the field of English language teaching (ELT) programmes worldwide. This in turn helps professionals keep up with the latest knowledge, and update their information.

Needs assessment is also fundamental because it helps teachers manage difficult situations, build confidence and enhance their personal development opportunities to the staff which in turn requires constant needs assessment so as to advance their teaching carrier particularly EFL TAs who are in dire need of continuous assessment of their. On the other hand, professional development is defined as any attempt to increase teachers' professional knowledge both during and after the preparatory stages (Craft, 1996; Johnson \& Golombek, 2011). English language teaching experts believe that perpetual professional development is of focal significant due to today's rapidly technological changing world (Alibakhshi \& Dehvari 2015).

Richards (1998) views professional development as a process that involves teachers' preparation of their own teaching methodology taking into account their experiences, beliefs and perceptions of good teaching. More specifically, Richards and Farrell (2005) refer to professional development as involving "examining different dimensions of a teacher's practice as a basis for reflective review" (p.4). For years, professional development was seen as "staff development" or "in-service training programs, focusing on providing teachers with information and suitable materials to promote and enhance their teaching knowledge" (Che \& Che, 2015, p. 4). Nevertheless, in recent years there has been a change in the notion of professional development considering it as orderly systematic plans to help teachers grow in their profession (Villegas-Reimers, 2003). Within this new perspective, novice teachers gain support to become reflective practitioners (Saberi \& Amiri, 2016). Therefore, according to Saberi and Amiri (2016), the concept of teachers' professional development has been viewed as a perpetual process focusing on planned and systematic activities which aims at triggering the teachers' growth in their profession. Reviewing the literature on Saudi teachers' professional needs and development shows that there is little published research conducted in this field. The topic of professional needs and development is, therefore, still under research in Saudi Arabia.

\subsection{Professional Development Needs of Saudi EFL TAs}

A considerable number of Saudi EFL teachers are professionally and linguistically 
incompetent in addition to not having a strong hold of methods of teaching language. A lot do not have the theoretical background knowledge of the basic factors of second language learning such as motivation, aptitude, age and attitude. The incompetency also appears in the lack of sufficient knowledge of strategies to teach language skills, grammar, and vocabulary. In addition, the use of educational aids and technology are lacking. Some English teachers also do not have the experience needed in material design, evaluation and adaptation (AL-Seghayer, 2014).

Zaid (1993) holds that there should be more emphasis on the communicative competence of English teachers during their careers where they can gain more experience from in service teachers. This call is reflected by several researchers (Al-Hazmi, 2003; Al Seghayer, 2005; Al Seghayer, 2014; Khan, 2011; Rahman \& Al haisoni, 2013; Zafer, 2004; Zohairy, 2012) who encourage the employment of a systematic approach to Saudi EFL teacher - preparation programs because the current programs are not enough for the preparation of Saudi EFL teachers, especially in the field of disciplinary knowledge (e.g. history of language - teacher, second - language acquisition, phonology, syntax), Pedagogical content knowledge (e.g. curriculum planning, assessment, classroom management, teaching the four skills) and technological knowledge (e.g. the ability to integrate the most recent technology into language teaching). In addition, the time allocated to pre-service EFL teachers during their practicum sites need to be extended in order to allow teachers to gain more extensive and intensive practical experience. So, instead of focusing on the last semester to do their practice, prospective teachers should engage in gradual training throughout their university life. These gradual practice opportunities should begin from the first semester of the third year by having experienced teachers involved in observing the amount of teach talk, types of tasks, techniques, and other instructional technologies. This in return can help teachers to grasp more practical experience.

\subsection{Linguistic, Pedagogical and Technological Competences}

Fillmore and Snow (2000) confirm the importance of educational linguistics. By this, they mean knowledge about language that promotes teacher's practice by helping them work with their language learners. Therefore, Fillmore and Snow (2000) suggested that teachers should have knowledge about oral and written language such as regular and irregular forms in English, dialect regularity, vocabulary development, correctness and quality in writing. They suggested courses to allow teachers to learn basic language information which includes second language teaching and learning academic discourse and text analysis.

Most English teachers all over the world are not native speakers. It is not necessary to have the command of native speakers' knowledge but the most important thing is to be a competent teacher (Canagarajah, 1999). Success lies in how much knowledge a teacher possesses in order to teach effectively and how far a teacher is proficient in the other aspects of teaching (Khamhi-Stein, 2009). Competency of EFL teachers includes maintaining use of the target language in the classroom, providing input and correcting learners immediately on the spot.

Richards (1998) proposes six dimensions of knowledge base: "theories of teaching" which refer to theoretical bases for approaching teaching, "teaching skills" that is related to the essential dimensions of teaching repertoire, "communication skills and language proficiency" 


\section{MInstitute Macrothink $_{\text {Int }}$}

which refers to language competence, "subject matter knowledge" that is focused on teacher's knowledge about their subject, theories, and the "disciplinary knowledge" that constitutes the theoretical basis for the field of second language teaching, pedagogical reasoning and decision making that refers to a purposeful professional development, problem solving and reflection which undergoes teaching practices. Finally, contextual knowledge which refers to educational and linguistic polices of speech community. The fulfillment of these diminutions can broaden EFL teachers with the bases of their classroom realities and develop their educational practices (Fandiño, 2013).

Grossman (1990) assigns four areas of teacher knowledge as the bases of professional knowledge for teaching: "pedagogical knowledge, subject matter knowledge, pedagogical content knowledge, and knowledge of context" (p. 5). However, the most important area is that which is related to the teachers' behavior and decisions in the classroom. So, teachers' way of organizing the classroom, explaining rules or using concrete materials are ways of assisting students to absorb the material they study and hence learn the language easily.

Identifying weaknesses and strength of EFL teachers towards their professionalism relies on knowing EFL beliefs of their knowledge base. Once they refined their beliefs about language learning, they can enhance their own learning and development (Al-bidawi, 2015). EFL teachers need to be developed in various areas, specifically in language skills, linguistics, classroom management, problem-solving, their pedagogy of various teaching techniques and effective language learning evaluation which is suitable to the content of the EFL curriculum (Al-Mekhlafi, 2007; Alkhwaldah, 2011). One more important tool for EFL teachers to boost their professional development is the use of technology in the educational process. For example, digital tutorials, multimedia CDs, and the web links can provide a limitless source of sound, animation, videos and multimedia that can help the learners to learn the content within a meaningful context (Dukes, 2005).

Because of the innovations in (CALL), it is focal to be aware of the publications that focus on technology. For instance, Arnold (2013) and Hubbard (2008) suggested that teacher educators should help teachers integrate any new technology, in their educational process. Arnold and Ducate (2006) used data from surveys to show that online discussions were of great benefit in creating interactions and enhancing a stronger understanding of the course material. In the same way, Scott (1998) reported that the use of the internet has developed TA reflection. Lee (2009) found that online discussions between each other and experienced teaches were more effective and influential than their face-to-face interactions.

\subsection{Related Studies}

Many researchers have investigated different aspects of teachers' and instructors' needs. However, it is safe to say that no study has tackled all of the linguistic, pedagogic and technological needs of Saudi teachers and instructors. Furthermore, as far as the researcher is interested, this is also the first study to examine Saudi university EFL teaching assistants' linguistic, pedagogic and technological needs.

Jokey (2007) assessed the level of linguistic competency_of45 Iraqi EFL teachers. The study found that EFL teachers were not as efficient as expected in performing certain language functions. In addition, Zhan (2001) investigated teachers' perceptions of the knowledge and 
skills required for EFL teachers' professional development at a university level in China. EFL teachers suggested that they need to improve their four basic communication skills as well as their knowledge pertaining to classroom teaching. Furthermore, Raheem (2007) assessed the oral efficiency of 50 Iraqi EFL primary school teachers. The results revealed that Iraqi primary school teachers of English lack the mastery of the elements of oral proficiency.

In the Saudi context, Al-Harbi (2006) examined the training needs of 551 in-service Saudi EFL teachers and found a shocking lack of competencies.. The results showed that EFL teachers were in dire need of more training in teaching methods, teaching the four language skills, classroom management and the use of teaching aids and technology. Also in the Saudi context, Zohairy (2012) investigated the professional of Saudi EFL teachers in seven state universities and four private universities. The results were that only two universities out of the eleven offered EFL instructors training opportunities.

Kildan, Ünali̇bret, Pektaş, Aydınözü and İncikabı (2013) found out that teacher trainees felt insufficient especially in curriculum and content knowledge, and that teaching practice and school experience courses were not adequate to their profession. On the contrary, Shah, Hussain and Nasseef (2013) revealed that instructors perceive themselves as competent teachers, who expressed confidence in their teaching skills, excellent language proficiency, background knowledge and experience of Saudi context and their adaptability to meet the learners and administered expectation.

Son, Robb and Charismiadji (2011) explored the perception of Indonesian EFL teachers of their computer knowledge and factors that affect their use of computers. The results revealed that participants did not have competency towards the use of computer courses, though they had positive attitudes toward the use of computer. Son, Robb and Charismiadji stressed on training that can develop teachers' skills and competencies in the use of CALL for their teaching practices and professional development. On the same concern, Mc Neil (2013) specifically explored Korean in- service teachers' learning experiences and suggested that teachers need a learning training course on CALL skills.

Dashtestani (2012) proved that Iranian EFL teachers maintain positive attitudes towards the use of CALL and that they saw computers as essential to their courses. However, Dashtestani observed that the teachers' attitudes towards CALL were inconsistent with their practical use and this requires renewing programmes and teacher training courses.

Alkhwaldeh (2011) investigated the professional needs of Jordanian English language teachers. The study revealed various professional needs on the part of EFL teachers including the need for effective organization of the EFL curriculum, securing facilities for effective English language instruction, encouraging students' motivation towards English language, the need of engaging teachers in collaborative learning and the necessity need of effective in-service training of English language teachers. Alkhwaldeh also emphasized that teachers of English should use a lot of teaching methods that affect and address the various needs of school students avoiding traditional methods of teaching that have already proved their failure.

The literature review emphasizes the importance of the needs assessment of TA's professional development, which could reform the TAs teaching performance to an astonishing degree. A 
common agreement in the literature has been observed concerning the necessity of TAs' needs assessment as a focal factor of enhancing the TAs knowledge and competences and as a means of equipping them with up-to-date techniques that will propel them into more efficiency in conducting their tasks. Furthermore, literature reveals that assessing teachers' competencies may serve as a means of evaluating their training adequacy. In spite of the sufficient number of studies on the needs assessment of teacher's competencies, none encompasses the three areas which this study has fully addressed in order to motivate TAs toward linguistic and pedagogic competencies as well as the need for technological knowledge.

To sum up, it is clear that the review of literature is highly related to the necessity of the needs assessment of TA's linguistic competence, pedagogical competence, as well as their technological knowledge. In addition, these studies show that most EFL TAs are in dire need of improving their linguistic as well as pedagogical competencies and that they are still not up to the mark concerning the latest technologies used in teaching English as a foreign language. They still need to avail themselves of the most updated technologies to be integrated to the learning environment. Therefore, these needs require EFL TAs to be involved in various professional development programs and activities in order to assist learners to be competent learners. Similarly, this study attempts to assess the professional development needs of EFL TA in IMSIU. The researcher divided EFL teachers' professional needs into three areas: the linguistics competence, the pedagogical competence as well as the technological knowledge needed for a better educational environment. In the light of the related literature and to the researcher's best knowledge, few studies were conducted on the needs assessment of TA's professional development in Saudi universities and probably none at IMSIU.

\section{Methodology}

\subsection{Research Design}

The quantitative research design used is a descriptive one as the subjects and the variables of the study were measured only once. Data were collected and the results were analyzed statistically using mean values and standard deviation to measure the degree of importance of the needs for professional development of EFL teaching assistants in term of the three dimensions: linguistic competence, pedagogic competence and technological knowledge.

\subsection{Population and Sample of the Study}

The population of this study consisted of all Saudi male and female EFL TAs who were working in the department of English Language and Literature at Al Imam Mohammad ibn Saud Islamic University in the academic year 2016-2017. They were 56 male and 96 female total of 152 EFL TAs. The sample of this study consisted of 32 male and 52 female EFL TAs. The questionnaire was sent by e-mail to all EFL TAs working at the university. The researcher received 84 responses from both male and female out of 152.Female TAs constituted $61.9 \%$ of the sample and male TAs constituted $38.1 \%$ of the sample Instrument of the Study

\subsection{Instrument of the Study}

The questionnaire used in this research was adopted from previous studies (Alkhawaldeha, 
2011; Dashtestani, 2012; Grossman, 1990).The five-point Likert-type questionnaire was mainly based on close ended questions. The questionnaire consisted of dimensions related to the needs required for professional development of EFL TAs; linguistic needs, pedagogic needs and technological needs. A pilot study was conducted in order to verify the reliability of the questionnaire. A sample of 15 EFL TAs who were teaching during the second academic term 2016-2017 in the English department at IMSIU in Riyadh. To achieve content validity of the questionnaire, the research instrument was revised by a validation committee of four professors and specialists in applied linguistics. Minor modifications were made upon their recommendations. The professors' comments, whether additions or deletions, were taken into consideration when preparing the final version of the questionnaire. Furthermore, using Cronbach's Alpha reliability coefficient as shown in Table 2, the calculated reliability was .788 which is high enough to conduct the study. This means that the instruments would give consistent results with all the participants' responses.

\subsection{Data Collection and Analysis}

Respondents were initially given two weeks to respond to the questionnaire. Two email reminders were sent the following week to those who did not respond. Data were collected after three weeks. The researcher received (84) responses from both male and female. The EFL TAs' perceptions of their required needs of their professional development were explored through the analysis of their responses on the questionnaire. Descriptive and inferential statistical techniques were used in the study. The researchers used the Statistical Package for the Social Sciences (SPSS) to analyze the answers statistically. The level of agreement in the scale was established by obtaining the 'range' by deducting the lowest value from the highest value on the scale ( 5 = very high, $4=$ high, 3 = medium, $2=$ weak, $1=$ very weak), equaling 4 .

\section{Results and Discussions}

To answer the research questions, percentages, means and standard deviations of the individual items for each dimension were calculated. In addition, the mean value and standard deviation was calculated as a whole for each major dimensions of the questionnaire: EFL teaching assistants' linguistic, pedagogic and technological needs.

\subsection{Results Related to the First Research Question}

The means and standard deviations of EFL TAs' responses were calculated for the individual items of "Linguistic Competence" dimension as well as the overall average of means and standard deviations for this dimension as displayed in Table 1.Subsequently, the overall findings were revealed and classified based on the interpretation scale mentioned earlier.

Table 1. Means and standard deviations of EFL TAs' Responses on linguistic competence needs

\begin{tabular}{llll}
\hline $\mathbf{N}$ & \multicolumn{1}{c}{ Item } & Mean & SD \\
\hline 1 & Enhancing academic speaking skills. & 4.35 & 0.976 \\
2 & Enhancing academic writing skills. & 4.45 & 0.926 \\
3 & Enhancing academic reading skills. & 4.02 & 1.119 \\
4 & Enhancing academic listening skills. & 3.93 & 1.117 \\
5 & Enhancing Presentation skills. & 4.04 & 1.08 \\
\hline
\end{tabular}


6 Developing English language Knowledge.

$4.13 \quad 0.979$

7 Engaging in off-campus training to interact with native speaker. 3.93

0.991

8 Participating in language programs directed by native speakers.

3.73

1.144

9 Training in how to publish internationally.

$4.02 \quad 0.944$

Average

$4.0667 \quad 1.03067$

Table 1 presents the means and standard deviations of TAs' perceptions toward their linguistic competence needs. The table shows that the mean of the responses ranged between (3.73-4.45) with standard deviation ranged between (0.926-1.144).In addition, "Enhancing academic writing skills" was perceived as the most necessary when it comes to linguistic competence with a mean value of $4.45(\mathrm{SD}=0.924)$. Subsequently, "Enhancing speaking skills" were rated second with a mean value of 4.35 (SD =0.976). Furthermore, it can be observed that "Participating in language programs directed by EFL native speakers" was the least rated with mean value of $3.73(\mathrm{SD}=1.144)$. The overall average mean value of the whole dimension was 4.0667 which was scored as the second needed dimension in response to the other dimensions.

\subsection{Results Related to the Second Research Question}

The means and standard deviations of EFL TAs' responses were calculated for the individual items of "Pedagogical Competence" dimension and the overall average of mean and standard deviation for the whole dimension as displayed in Table 2. Subsequently, overall findings were revealed and classified based on the interpretation scale mentioned earlier.

Table 2. Means and standard deviations of EFL TAs' responses on pedagogic competence needs

\begin{tabular}{|c|c|c|c|c|}
\hline Number & Item & Mean & SD & Ranking \\
\hline 1 & The major theories of language, teaching / learning & 3.99 & 0.898 & 4 \\
\hline 2 & $\begin{array}{l}\text { Solving pedagogical problems and developing } \\
\text { teaching strategies. }\end{array}$ & 4.11 & 0.776 & 2 \\
\hline 3 & $\begin{array}{l}\text { Using effective teaching methods to motivate } \\
\text { students to learn. }\end{array}$ & 4.4 & 0.838 & 1 \\
\hline 4 & Attending courses in classroom management. & 3.64 & 0.94 & 9 \\
\hline 5 & $\begin{array}{l}\text { Provision of basic teaching items such as teachers' } \\
\text { books and manuals. }\end{array}$ & 3.86 & 0.894 & 6 \\
\hline 6 & $\begin{array}{l}\text { Attending courses in language curriculum } \\
\text { development and evaluation. }\end{array}$ & 4.04 & 0.884 & 3 \\
\hline 7 & $\begin{array}{l}\text { Attending overseas courses to improve teaching } \\
\text { skills. }\end{array}$ & 3.79 & 1.019 & 8 \\
\hline 8 & $\begin{array}{l}\text { Provision of adequate books, journals and other } \\
\text { reference materials. }\end{array}$ & 3.86 & 0.852 & 7 \\
\hline \multirow[t]{2}{*}{9} & Attending courses in effective lesson delivery. & 3.95 & 0.943 & 5 \\
\hline & Average & 3.96 & 0.89378 & \\
\hline
\end{tabular}




\section{Macrothink}

Table 2 presents the means and standard deviations of the TAs' perceptions toward their pedagogic competence. The Table shows that the mean of the responses ranged between (3.79-4.4) with standard deviation ranged between (0.776-1.019). "Using effective teaching tools, techniques and methods to motivate students to learn and enhance learning outcomes" has been considered by respondents as most needful. It has received the highest mean value of 4.4 (SD 0.838). Subsequently, "Training in how to solve pedagogical problems and develop alternative strategies for teaching" was perceived as the second most important need where the mean value is 4.11 (SD 0.776). Furthermore, "Attending courses in language curriculum development and evaluation" had been identified as the third most important need with mean value 4.04 (SD .884). "Attending courses in large classroom management" received the least mean value of 3.64 (SD 0.94) marking it as the ninth and least important need. The overall average mean value of the whole dimension was 3.96 which was the least scored in response to the other dimensions.

\subsection{Results Related to the Third Research Question}

The percentage, mean and standard deviation of EFL TAs' responses were calculated for the individual items of "Technological Knowledge" dimension and the overall average of mean and standard deviation for the whole dimension as displayed in Table 3. Subsequently, overall findings were revealed and ranked based on mean and standard deviation.

Table 3. Means and standard deviations of EFL TAs' responses on technological knowledge needs

\begin{tabular}{lllll}
\hline Number & Item & Mean & SD & Ranking \\
\hline 1 & Attending courses in effective lesson delivery. & 4.12 & 0.949 & $\mathbf{4}$ \\
2 & Providing teacher assistants with the software. & 4.35 & 0.857 & $\mathbf{1}$ \\
3 & Workshops on implementing CALL in EFL courses. & 4.23 & 0.910 & $\mathbf{3}$ \\
4 & Attending programs and sessions on t CALL. & 3.94 & 0.949 & $\mathbf{7}$ \\
5 & Providing teacher assistants with CALL facilities. & 4.31 & 0.821 & $\mathbf{2}$ \\
6 & How to use software in linguistic research. & 4.12 & 0.949 & $\mathbf{5}$ \\
7 & cooperating in CALL materials production projects & 3.76 & 1.001 & $\mathbf{8}$ \\
8 & Updating EFL teacher assistants about new CALL & 4.11 & 0.807 & $\mathbf{6}$ \\
& software periodically. & 4.118 & 0.90538 & \\
\hline
\end{tabular}

Table 3 presents the means and standard deviations of TAs' perceptions toward their technological knowledge. The Table shows that the mean of the responses ranged between (3.76-4.35) with standard deviation ranged between (0.807-1.001). "Providing teacher assistants with the necessary software to be used in EFL courses" has been considered by respondents as most needful. It has received the highest mean value of 4.35 (SD 0.857). Subsequently, it has been followed by "Providing EFL teacher assistants with adequate classroom facilities to implement CALL" which received the mean value of 4.31(SD 0.821).furthermore, "Holding workshops and meetings in how to implement CALL in EFL courses" was the third most important need with mean value 4.23 (SD .910). "Attending 


\section{MInstitute Macrothink $^{\text {Int }}$}

awareness-raising programs and sessions on the uses and benefits of CALL" has received the mean value of 3.94(SD 0.949) marking it as seventh. Finally, the lowest mean value of 3.76 (SD 1.001) was received by "Inviting EFL teacher assistants to cooperate in CALL materials production projects" which marks it as the eighth and least important item. The overall average mean value of the whole dimension was 4.118 which was the highest score in response to the other dimensions.

\section{Discussion}

\subsection{EFL Teaching Assistants Perceptions of Their Linguistic Needs}

The researchers observed that linguistic competence was perceived as the second important need in respect to the other dimensions. The majority of the items of the first dimension received very high responses. The researchers believe that this result is in agreement with some of Jokey (2007) who found that EFL teachers were not as efficient as expected in performing certain language functions. There were errors in their pronunciation and inappropriate use of words. The findings of the current study also confirm the findings of Raheem (2007) who asserted that EFL primary school teachers should be assessed. The results revealed that Iraqi primary school teachers of English lack the mastery of the elements of oral proficiency. Furthermore, the findings of the current study match those observed by Alkhawaladah's study in (2011) who stressed the need for off-campus course administered to EFL learners in order to engage with native speakers of the English language and the need for in-service teacher training that contribute positively to improve learners' learning.

The results of the first question showed that the Saudi EFL teaching assistants' perceptions towards their professional development linguistic needs were within the degree of high but they were different in ranks. This finding supports the finding of Igawa (2008) whose findings indicated that EFL teachers were in dire need to be trained in certain areas such as communication of skills, language improvements attending conferences and workshops. This awareness can bring better insight of EFL teachers' perceptions towards their professional development. It also matches those findings of Zhan (2001) showed that communicative skills scored as the most important skills of Chinese EFL teachers. EFL teachers suggested that they need to improve their four basic communication skills.

A detailed interpretation of the results revealed that EFL TAs need to enhance their communication skills, basically speaking and writing. Overall, it is observed through the findings that the highest items scored in the first dimension were part of the linguistic competence. Carroll (1968) mentioned that linguistic competence is the aspect of productive and receptive skills, e.g. listening, speaking, reading and writing skills and how components of linguistic competence are related to each skill. This indicates the importance of linguistic competence and EFL TAs are in dire need of these aspects and so they need more handling. This echoes Al-Seghayer (2014) when he admitted that Saudi EFL teachers need to build their linguistic competence.

\subsection{EFL Teaching Assistants Perceptions to Their Pedagogical Needs}

The result of the second question showed that pedagogic competence needs scored the least mean value in respect with the other dimensions. It also showed that the majority of the items has a mean value less than Four except for three items. The most important need as perceived 
by respondents was "using effective teaching tools, techniques and methods to motivate students to learn and enhance learning outcomes". This finding exactly matches Igawa's (2008). Igawa indicated that teachers need professional development in teaching skills and methods which was scored as the most required need, language improvement only for non-native speaking teachers as well as general communication skills. Furthermore, "Training in how to solve pedagogical problems and develop alternative strategies for teaching" was perceived as the second most important need. The finding confirms those of Alkhwaldeh (2011) whose study revealed various professional needs on the part of EFL teachers including the need for effective organization of EFL curriculum, securing facilities for effective English language instructor, encouraging students' motivation towards English language, the need of engaging teachers in collaborative learning and the necessity of effective in- service training of English language teachers.

\subsection{EFL Teaching Assistants Perceptions to Their Technological Needs}

The technological knowledge has the highest mean value with respect to the other dimensions. "Providing teacher assistants with the necessary software to be used in EFL courses" has been considered by respondents as most needful. This result matches those observed by Dashtani (2012) who asserted that most obstacles are due to the lack of knowledge in implementing CALL in their teaching practices, lack of CALL facilities in EFL courses, appropriate software that can be used in EFL courses are not easily available to EFL teachers.

The researchers found that "Providing EFL teacher assistants with adequate classroom facilities to implement CALL" had also received high acceptance from respondents as it had ranked second most important need. This result goes hand in hand with the findings of Nim Park and Son (2009) who found that teachers had positive attitudes towards the use of CALL in EFL courses. The EFL teachers believed that computers were essential to provide them with input as well as authentic contexts for students. However, they stated that there are external and internal obstacles in implementing CALL. Some of the external factors were inadequate computer facilities and lack of time. Overall, these high scores in the perception of teachers toward technological needs is an indication of their willingness to implement CALL and they are eager to know more about CALL. However, policy makers should not ignore the other dimensions because each one is a completion of the other. Moreover, English language teaching experts believe that perpetual professional development is of focal significance due to today's rapidly technological changing would (Alibakhshi \& Dehvari, 2015).

\section{Conclusion}

The central questions in this study are concerned with the professional development needs in terms of their linguistic, pedagogic and technological competence. As for the results of the first research questions, The Saudi EFL teaching assistants' perceptions towards their professional development of their linguistic competence showed that the majority of the first dimension has a mean value greater than 4 . More importantly, the very high needs of linguistic competence were enhancing academic writing skills and enhancing academic speaking skills. Because writing skills and speaking skills are basic criteria for communication skills they are the most needful needs for TAs to focus on. 
With regard to the second dimension which is concerned with the Saudi EFL teaching assistants' perceptions towards their pedagogic needs, there were very high needs observed statistically. Thus, it is apparent that teaching assistants, when exposed to different pedagogical situations, were not experienced enough to deal with them which indicates that they need more practice. The findings from the third question about the technological knowledge dimension were needed for teaching assistants to flourish academically. Unexpectedly, the most required need of the three competencies was the technological knowledge which has the highest mean in respect to the other dimension. This high scored mean in their perception towards technological needs is an indication of their willingness to implement CALL and so policy makers should put into account this particular dimension as one of the most needful need for teaching assistants so as to keep pace with the most up-to-date technology of teaching..

Through this study, it is clear that EFL teaching assistants should be constantly assessed linguistically, pedagogically as well as technologically because they bear a great responsibility towards their students. Therefore, identifying the needs of teaching assistants can help in the process of nourishing the academic teaching at higher institutions such. So, the findings of the three dimensions of competencies indicated that more insight into the current quality of teaching assistants at IMSIU is highly required. Therefore, this study can be viewed as feedback to policy makers concerning the inadequacy of the current TAs' linguistic, pedagogic and technological competencies for the sake of findings a more rigorous vision of teaching assistants' needs.

\section{Recommendations}

This study demonstrated that a needs assessment of Saudi teaching assistants is necessary and the evidence is clear through the findings of the study. Therefore, it is recommended that teaching assistants are helped through the following recommendations. Furthermore, more EFL courses should be available to EFL teaching assistants and EFL classes should be equipped with suitable technological tools. In addition, the perceptions of teaching assistants of the importance of their linguistic pedagogical and technological competences indicate a need for greater emphasis on such topics in the courses held for their development at their university.

As for further research, the findings of the present study highlight as well as extend our insight into the Saudi TAs' needs and potentials. Therefore, this study provides many questions in need of more investigation in the future. Similar qualitative research is required in this area. Furthermore, similar research on other populations is also required to assess the needs of language lecturers and even professors.

\section{Limitations of the Study}

This study was conducted on EFL TAsin the English department at Al-Imam Mohammad Ibn Saud University during the second semester of the academic year 2016-2017. Furthermore, the study was largely dependent on the quantitative approach with a Likert-type scale, closed-ended questions questionnaire and this resulted in limitations on responses. However, interviews could have added more depth to the research. In addition, the nature of professional development needs for EFL TAs themselves keep changing from time to time. 


\section{References}

Al-Bidawi, S. (2015). EFL Faculty Members' Professional Development: Beliefs and Suggestions. Journal of Modern Education Review, 5, 970-977. https://doi.org/10.15341/jmer(2155-7993)/10.05.2015/005

Al-Harbi, A. (2006). Training Needs of English Teachers in Al-Qassim Province. Unpublished master's thesis, King Saud University, Riyadh, Saudi Arabia.

AL-Hazmi, S. (2003). EFL teacher preparation programs in Saudi Arabia: Trends and challenges. TESOL Quarterly, 37(2), 341-344. https://doi.org/10.2307/3588509

Alibakhshi, G., \& Dehvari, N. (2015). EFL Teachers' Perceptions of Continuing Professional Development: A Case of Iranian High School Teachers. Profile Issues in Teachers Professional Development, 17(2), 29-42. https://doi.org/10.15446/profile.v17n2.44374

Alkhawaldeh, A. (2011). The professional needs of English language teachers at Amman 1st and 2nd directorates of education. College Student Journal, 45(2), 376-393.

Al-Mekhlafi, A. (2007). The development of prospective EFL teachers' specialist language competencies in UAE universities. University of Sharjah Journal for Shari'a Sciences \& Humanities, 4(1), 2-27.

Al-Seghayer, K. S. (2005). Teaching English in Saudi Arabia: Slowly but steadily Changing. In G. Braine (Ed.), Teaching English to the world (pp. 115-130). Mahwah, NJ: Lawrence Erlbaum Association.

Al-Seghayer, K. S. (2014). The actuality, inefficiency, and needs of EFL teacher-preparation programs in Saudi Arabia. International Journal of Applied Linguistics and English Literature, 3(1), 143-151. https://doi.org/10.7575/aiac.ijalel.v.3n.1p.143

Angus, K. (2014). Meeting the needs of foreign language teaching assistants: Professional development in American universities. The University of Arizona.

Arnold, N. (2013). The role of methods textbooks in providing early training for teaching with technology in the language classroom. Foreign Language Annals, 46(2), 230-245. https://doi.org/10.1111/flan. 12020

Arnold, N., \& Ducate, L. (2006).Future foreign language teachers' social and cognitive collaboration in an online environment. Language Learning \& Technology, 10(1), 42-66.

Canagarajah, A. S. (1999). Interrogating the "native speaker fallacy;" Non-linguistic roots, non-pedagogical results. In G. Braine (Ed.), Non-native educators in English language teaching (pp. 77-92). Mahwah, N.J.: Lawrence Erlbaum.

Carroll, J. B. (1968). The psychology of language testing. In Language testing symposium: A psycholinguistic approach (pp. 46-69).

Che, O., \& Che, M. Z. (2014). The need for in-service training for teachers and its effectiveness in school. International Journal of Innovation Education and Research, 2-11, $1-9$.

Craft, A. (1996).Continuing professional development: A practical guide for teachers and schools. London, UK: Open University Press.

Cronbach, L. J. (1951). Coefficient alpha and the internal structure of tests. Psychometrika, 16(3), 297-334. https://doi.org/10.1007/BF02310555 
Dashtestani, R. (2012). Barriers to the implementation of CALL in EFL courses: Iranian EFL teachers' attitudes and perspectives. The jalt call Journal, 8(2), 55-70.

Day, R. (1993). Models and the knowledge base of second language teacher education. University of Hawai'i Working Papers in English as a Second Language 11 (2).

Dukes, C. (2005). Best practices for integrating technology in English language instruction. ELL \& Technology-Southeast Initiatives Regional Technology in Education Consortium, 7(1), 3-6.

Fandiño, Y. (2013). Knowledge base and EFL teacher education programs: a Colombian perspective. Íkala, revista de lenguaje y cultura, 18(1), 83-95.

Fillmore, L. W., \& Snow, C. E. (2000). What teachers need to know about language. ERIC Clearinghouse on Languages and Linguistics, Washington, DC.

Grossman, P. L., (1990). The making of a teacher: Teacher knowledge and teacher education. New York: The Teachers College Press.

Hopkins, K. D., Stanley, J. C., \& Hopkins, B. R. (1990).Educational and psychological measurement and evaluation. Needham Heights, MA: Allyn \& Bacon. https://doi.org/10.1177/0013164490504001

Hubbard, P. (2008). CALL and the future of language teacher education. CALICO, 25(2), 175-188.

Igawa, K. (2008). Professional development needs of EFL teachers practicing in Japan and Korea. International Buddhist University Bulletin, 45, 431-455.

Johnson, K. E., \& Golombek, P. R. (2011).Research on second language teacher education: A sociocultural perspective on professional development. New York, NY: Routledge.

Jokey, M. (2007). An Assessment of Intermediate School EFL Teachers' Classroom English. Thesis: University of Baghdad. https://doi.org/10.4324/9780203844991

Khamhi-Stein, L. D. (2009). Teacher preparation and nonnative English-speaking educators. In A. Burns \& J. C Richards (Eds.), The Cambridge guide to second language teacher education (pp. 91-101). Cambridge: Cambridge University Press.

Khan, I. A. (2011). Professional Development of English Teachers: The Saudi Arabian Context. Interdisciplinary Journal of Contemporary Research in Business, 3, 1583-1591.

Kildan, A. O., Ibret, B. U., Pektas, M., Aydinozu, D., Incikabi, L., \&Recepoglu, E. (2013).Evaluating Views of Teacher Trainees on Teacher Training Process in Turkey. Australian Journal of Teacher Education, 38(2). https://doi.org/10.14221/ajte.2013v38n2.10

Lee, L. (2009). Scaffolding Collaborative Exchanges Between Expert and Novice Language Teachers in Threaded Discussions. Foreign Language Annals, 42(2), 212-228. https://doi.org/10.1111/j.1944-9720.2009.01018.x

Nim Park, C., \& Son, J. B. (2009).Implementing computer-assisted language learning in the EFL classroom: Teachers' perceptions and perspectives. International Journal of Pedagogies and Learning, 5(2), 80-101. https://doi.org/10.5172/ijpl.5.2.80

Raheem, R. (2007).Oral Proficiency of EFL Primary School Teachers in Iraq. M.A. Thesis: the Arabic Higher institute for Educational and Psychological Studies. University of Baghdad. 


\section{Macrothink}

Rahman, M., \& Alhaisoni, E. (2013).Teaching English in Saudi Arabia: Prospects and challenges. Academic Research International Journal, 4(1), 112-118.

Richards, J. C. (1998). Beyond Training: Perspectives on language teacher education. New York: Cambridge University Press.

Richards, J. C., \& Farrell, T. S. C. (2005). Professional Development for Language Teachers: Strategies for Teacher Learning, Cambridge: Cambridge University Press. https://doi.org/10.1017/CBO9780511667237

Saberi, L., \& Amiri, F. (2016). A Qualitative Study of Iranian EFL University Teachers' Attitude towards Professional Development. Journal of Language Teaching and Research, 7(3), 591-598. https://doi.org/10.17507/jltr.0703.22

Scott, V. M. (1998). Exploring the link between teaching and technology: An approach to TA development. New Ways of Learning and Teaching: Technology and Foreign Language Education, 3-18.

Shah, S. R., Hussain, M. A., \& Nasseef, O. A. (2013). Factors Impacting EFL Teaching: An Exploratory Study in the Saudi Arabian Context. Arab World English Journal, 4(3).

Sheshsha, J. A. (1982). The qualifications of a competent teacher of English in Saudi Arabia. Unpublished doctoral dissertation, Indiana University, Bloomington.

Son, J.-B., Robb, T., \& Charismiadji, I. (2011). Computer literacy and competency: a survey of Indonesian teachers of English as a foreign language. CALL-EJ, 12(1), 26-42.

Villegas-Reimers, E. (2003). Teacher professional development: an international review of the literature. Paris: International Institute for Educational Planning.

Warwick, D., \& Lininger, C. (1975). The Sample Survey: Theory and Practice, McGraw-Hill, New York.

Zafer, A. M. I. (2004). A survey of Saudi school teachers' and college professors' perspectives on topics and roles to emphasize in English as a foreign language in teacher preparation courses.Doctoral dissertation. University of Kansas, Lawrence, Kansas.

Zaid, M. (1993). Comprehensive analysis of the current system of teaching English as a foreign language in Saudi Arabian intermediate schools. Doctoral dissertation, University of Colorado, Bolder.

Zhan, J. (2001). Professional development of English (EFL) faculty members in a large comprehensive university. Doctoral dissertation, The University of Tennessee.

Zohairy, S. (2012). Professional development challenges and possible solutions. Saudi Preparatory Year English Program: The Future and Beyond: student, teacher, pedagogy and curricular issues, 162-183.

\section{Copyright Disclaimer}

Copyright reserved by the author(s).

This article is an open-access article distributed under the terms and conditions of the Creative Commons Attribution license (http://creativecommons.org/licenses/by/3.0/). 